\title{
Walter Block
}

Loyola University New Orleans

ORCID: 0000-0003-2215-4791

\section{Matthew Seaman}

Loyola University New Orleans

ORCID: 0000-0002-4667-4591

\section{Fahrenheit 451 and the Education System}

$27 / 2019$

Political Dialogues

DOI: http://dx.doi.org/10.12775/DP.2019.010

\begin{abstract}
:
We use this book as a launching pad to comment on the sad state of modern education. We are particularly critical of public schools, but even ostensibly private ones come under our microscope. Bradbury's book deprecates book burning. Our modern educational establishments have not yet taken up that practice, but by banning statues, precluding certain speakers from campus, biasing the professoriate in one direction, engaging in cultural Marxism, this may not lie all too far into the future.
\end{abstract}

Keywords: Education; Fahrenheit 451; book burning;

JEL category: I20

\section{Introduction}

Fahrenheit 451 by Ray Bradbury tells a story about Guy Montag, a fireman responsible, not for extinguishing fires, but for burning illegal books and destroying such dangerous sources of information. Montag's attitude about his job radically shifts as the novel proceeds, moving from being mostly appreciative of his work to an attitu- de of shame and remorse. He finally realizes the degree of brainwashing for which he is in part responsible. He then teams up with members of the fringes of society to work against the establishment. Despite resistance from his wife and his boss, captain Beatty, Montag escapes the police as nuclear war pummels his hometown.

In section II we highlight relevant points made by Bradbury, as they pertain to education. Section III is devoted to a discussion of several philosophies of education. The purpose of section IV is to delve into the failures of public schooling. The deterioration of education is the subject of section V. We conclude in section VI by considering several objections to our thesis.

\section{Fahrenheit 451}

Critics of the book like to discuss its main themes, including the optimal degree of free speech, the role of new technologies, and resistance to the authorities. A lesser explored topic is revealed by one of the last scenes of the novel. Granger, the leader of a book 
club composed of professors and other professionals, mentions to Montag: "when the war's over, some day, some year, the books can be written again, the people will be called in, one by one, to recite what they know and we'll set it up in type until another Dark Age." ${ }^{1}$ As destruction appears imminent to the country, the mission of Granger and his group of academics and intellects is to rebuild the nation on the basis of books. In other words, Granger saw books for their educational value rather than as a source for challenging political structures as the elites did. While Fahrenheit 451 says little directly about schools and universities, the novel indirectly touches on how we raise our students to learn about the world.

It is important to consider what is really meant by the term "education." For the typical person, the term signifies the mandatory primary and secondary schooling a child goes through. Then, if he decides to, it also includes time spent at college and in graduate programs. But education means not just time in educational institutions but also what someone learns outside of school. This can take places in sports, from family, spending time in activity with friends and so on. Thus, education signifies both schooling and valuable learning experiences in daily life.

Clarisse McClellan, Montag's neighbor, provides a model of what a strong education should do. When she first meets Montag, she makes a series of astute observations of which he is unaware. Although she shifts topics quickly, McClellan is knowledgeable in a wide variety of areas, including flowers, billboards - and the burning of houses.

\footnotetext{
${ }^{1}$ Bradbury 146
}

Montag responds to her ideas by stating "you think too many things," but her critical thinking skills should be honored. ${ }^{2}$ Montag himself has trouble responding to what she has to say, so he fills the void with laughter and other empty expressions. Due to the fact that he has worked in a field where expression of thought is discouraged, Montag is (at least so far in the story) unable to educate himself about the world. However, her thoughts show a commitment to analysis, reasoning, critical thinking, and curiosity. An ideal education would train someone in precisely these traits.

\section{Philosophies of education}

To further understand how an education would cultivate these factors, an examination of curiosity in particular is necessary. This characteristic is defined as a mental state where people explore the world around them and show an interest in many topics, just as McClellan did. Leslie (2015) demonstrates a correlation between curiosity and asking questions. By framing an open ended question that can have multiple answers, a person can create multiple avenues of exploration and begin a search to learn more about particular topics. The problem lies in the fact that "[q]uestion asking...is a sophisticated skill. People learn it in middle-class households and then in elite professional fields."3 Questioning has to be continually practiced if it is to be wielded effectively and eventually grow into curiosity.

\footnotetext{
${ }^{2}$ Bradbury 6

${ }^{3}$ Leslie 90
} 
Leslie goes on to describe how schools are supposed to operate as "a crucible of curiosity." In his model of education, JeanJacques Rousseau commented on the fact that a child does not need guidance from parents to learn the important points about life. Children are "taught by experience alone" and led by their instincts in deciding what path to take in learning. ${ }^{5}$ Rousseau believed parents interfere too easily with what they deem as important knowledge. ${ }^{6}$ What really happens because of any form of intervention in children's education is that they become less capable of thinking critically. Progressive schools went on to adopt the model spoken of by Rousseau, focusing less on specific subjects and more on developing students. ${ }^{7}$ If a child is led to explore where his passion is, ask questions, and find the answers himself, then he will find more satisfaction with his education.

The failure to nurture curiosity in students constitutes yet another problem. As pointed out by Murray Rothbard, the federal government has obtained a great amount of control in education and its goal is to cultivate a citizenry obedient to its vision. This means that the state determines what is essential for a child to learn. The model of education offered by the government runs contrary to a model of curiosity because there is no room to think outside the box and question what is taught. Teachers instead give the facts and tell a student what to think. Standardized tests are then administered evaluating children on how

\footnotetext{
${ }^{4}$ Leslie 108

${ }^{5}$ Leslie 109

${ }^{6}$ Ibid.

${ }^{7}$ Leslie 110
}

well they have memorized what the state deems as vital information. It means "inculcation of obedience to the State and to the 'group,' rather than the development of self-independence, for the deprecation of intellectual subjects."

Under current curricula, students are bored by this repetitive teaching method. Speaking of "the deprecation of intellectual subjects," as any educator realizes, people learn in different ways. For one person, looking at images with visual demonstrations helps for understanding a concept about biology. For another, writing vocabulary and its definition over and over in Spanish contributes to learning the language. With this fact in mind, Howard Gardner ${ }^{9}$ proposed the multiple intelligences theory. Students can best learn topics in schools in many ways: visually, linguistically, physically, musically, and by yet other means. This plan would help contribute to curiosity because more paths would be taken in trying to grasp a subject, i.e. there would be more room for exploration.

Freedom is another essential characteristic needed for a child to flourish educationally. Instead of adhering to a rigid structure telling a student what to learn and in which order, freedom means a child pursues the subjects that sparks his strong interest. One of the defining features of the modern world is the fact that people specialize in their work based upon the division of labor. Thousands of years ago, economic conditions made it essential to produce for self-consumption. This meant most people were farmers or fishermen trying to pro-

\footnotetext{
8 Rothbard 12

9 Gardner, 2006, 2011
} 
duce for their own wants and needs. In the modern era, accumulation of surpluses has freed up labor to work in more specialized tasks. Entrepreneurs need labor in areas as diverse as flight piloting, auto repair, and shoemaking. The structure of the modern economic world means children can afford to learn about a topic that seems interesting. With an ever-changing world, general training has overtaken in importance the narrow specialized variety, at least early on.

\section{Public schooling}

The problem with the public school system lies in the restriction of freedom. Instead of individual ownership, the state replaces personal choice with collective ownership. A general value among policymakers is the desire for equality between children. The concept seems innocent to many, but actually worsens educational services. "The result has been a tendency to regard every child as equal to every other child, as deserving equal treatment, and to impose complete uniformity in the classroom." ${ }^{10}$ So the bar remains set at the level of the lowest performer, therefore dumbing down teaching material and forcing students to learn the same lecture material despite different learning capabilities. In order to accommodate the lowest performing students, subjects have to be taught at the simplest level.

Does this mean that private schools are perfect? Of course not. However, ones that are particularly ineffective in their mission can lose students, and fees. Eventually, if they continue in their misbegotten ways, bankruptcy is an actual possibility. This

${ }^{10}$ Rothbard 12 salutary possibility of exit simply does not exist in the realm of public schooling, as a necessary condition of failure. Be a given state institution of learning ever so unsuccessful, it need never go broke. There is always the possibility, the likelihood, that tax revenues will be diverted to their coffers. They may not be too "big to fail" but they are indeed too "public to fail."

Bradbury also demonstrated the importance of freedom in education using the character Faber, a retired professor. The latter claimed society needs leisure time to appreciate books. Of course, many people have time off but what is actually needed is "time to think."11 Furthermore, society also needs to combine quality of information and leisure with "the right to carry out actions." 12 With "time to think," individuals can reflect more on what they have learned and form connections between areas of interest. Then, "the right to carry out actions" allows something to actually be done with the material learned. In other words, knowledge can be applied to the real world. All too many modern schools restrict Faber's form of freedom because much time is spent trying to complete assignments for a good grade rather than to learn anything of substance. Plus, statist schools tend to leave out tangible applications of what is taught.

It is simply natural for the school system to depend on restricted freedoms since it is run akin to a centrally planned body. Teacher Albert Shanker made a similar comment, writing that "public education operates like a planned economy, a bureau-

${ }_{11}$ Bradbury 80 
cratic system in which everybody's role is spelled out in advance and there are few incentives for innovation and productivity." ${ }^{13}$ Boaz (1990) goes on to cite the decline in district schools over time and the corresponding increase in students and parents in each district; likewise, funding from local government declined. ${ }^{14}$ The increasing amount of control given to a select few over how schools are run have result in lower performance. Part of what makes such a model outdated is the fact we live in an age where information acts as capital and is readily available to the public. "Wealth becomes virtually unlimited" and a large amount of power is given to the individual. ${ }^{15}$ In order for such an information economy to thrive, authority must be delegated to the individual level. With basic knowledge about local markets accessible through the internet, no central body is needed to solve problems about what means appear best to satisfy wants and needs. Under the Marxist way of thinking that unfortunately now dominates public schools, wealth is "primarily physical and finite." 16

\section{Deterioration of education}

In the light of increasing centralization and governmental takeover of educational functions, the philosophy of education has taken a dark turn. Over time, "[t]he state has become the saving institution, and the function of the school has been to proclaim a new gospel of salvation. Education... [is] a facet of the Enlightenment hope of regenerating man in terms of the promises of science and that new social order to be achieved in the state." ${ }^{17}$ A great trust exists among the people of Fahrenheit 451 in "the promises of science" bringing about new technology. However, science can only study the observable world and identify laws that govern the natural realm. Science, of course, has helped bring about advancements in material standard of living. Yet, the messianic view of science in education has put people in danger of false faith.

As a reflection of this philosophy, Horace Mann helped to shape the school system into what it is today. His ideas established "rights rather than responsibilities. Instead of being accountable to God, parents, teachers, and society, the pupil can assert that God, parents, teachers and society are responsible to him." ${ }^{18}$ Mann treated students to the status of being their own gods. Instead of creating the freedom needed for a flourishing education, Mann "destroy[ed] man's freedom in subservience to the common will." ${ }^{19}$ Teachers assume a role in which they are unable to help the student because of a system of total control for the pupil. Eventually, Mann's conception of education influenced John Dewey and others to enact reform in the education system.

Now consider the deteriorating economics of the education system. von Mises warned long ago about the problem of economic calculation in socialist communities. He described one of the advantages of using objective exchange value being "a control

\footnotetext{
${ }^{13}$ Boaz 2

$14 \quad 14-15$

15 Brookes

${ }_{16}$ Brookes
} 
over the appropriate use of goods." ${ }^{20}$ Under a sound price system, objective value can be compared to see whether a profit can be made. Furthermore, prices are a source of information about scarcity for a particular good. They also tell an entrepreneur about the forces of supply and demand operating in a market as well as subjective valuations on a particular good. Firms need market prices to calculate what would be the most rational allocation of resources. This is particularly relevant in the education field because dilemmas present themselves in whether to spend money on new teachers, more textbooks, renovated classrooms, or other class material. ${ }^{21}$ There is an absence of market prices in the current system as parents are given little choice in where to send their children to school. As a result, state test scores become the primary signal in determining the quality of a school and whether it is an attractive option to send students to. Basing evaluations on testing has only led to "little more than incentiviz[ing] teachers to focus on rigid state standards, encourage cheating, and disrupt valuable class time."22 Furthermore, since schools depend on tax payments, consumers of education services can only provide feedback about the system through electing bureaucrats. However, voters choose to elect a particular politician for many reasons other than just education.

Due to the nature of public schooling, the role of entrepreneurs in promoting higher quality educational services has been limited. However, authors such as Leisey (2000) have done an excellent job docu- menting the achievements of businessmen in promoting education. For example, Kay Fredericks founded TREND enterprises with its mission of making learning fun. ${ }^{23}$ Contributing in the field may have seemed difficult because Fredericks was a female in a male controlled business sector. ${ }^{24}$ Yet, her example showed that innovative minds can succeed in the educational field regardless of background. In a private enterprise system, the entrepreneur assumes risk and suffers considerable losses for not providing the service that the consumer wants. Ultimately, though, the business owner is motivated primarily to best serve his constituents by providing a better product than competitors. Fredericks thought there was a lack of products geared toward stimulating interest in learning, so she took advantage of what appeared to be a profit opportunity. Schools that bought her products turned out to be better off, since she notes "receiving accolades from teachers about how the products have transformed their classrooms, motivated children, and enriched the learning experience." ${ }^{25}$ Not only do "teachers" benefit, but the child is served by adding to "the learning experience."

In a free market system, payment of tuition would depend on "teacher quality, parental satisfaction, and operational efficiency (among countless others)." ${ }^{26}$ The overall level of services then determines the value of the education at a certain school and its price. For families living on a sensitive budget, the free market helps to provide

\footnotetext{
${ }^{23}$ Leisey 79

${ }^{24}$ Leisey 82

${ }^{25}$ Leisey 85

${ }^{26}$ Ibid.
} 
affordable options and gives choices to the parents. In addition, competition between schools ensures constant improvement in services including a better quality of teaching. One of the reasons for the general dumbing down of education includes the power of labor unions in promoting lower quality teachers and disadvantaging higher quality ones.

\section{Objections}

A couple of objections exist to a private schooling system. One includes the argument of asymmetric information: that parents are not equipped with the necessary information to make decisions regarding where to send their child to school. Just "as in health care, consumers do not have as much information as the professionals, and are therefore at a disadvantage... [ $\mathrm{t}$ ]he only way markets work effectively with asymmetric information is when consumers trust that suppliers are likely to act in the consumers' interest." ${ }^{27}$ However, according to Walberg \& Bast (2003) this problem can be solved through the fact that reputation and experience are ways to test the reliability of educational services. ${ }^{28}$ If an education provider intentionally chooses to sell lower quality services at an unfair price, consumers will catch on and spread the news about this situation. If the provider's reputation is damaged enough, he will have great difficulty selling his services, so business depends on at least a solid reputation in order to attract customers. Through experience, families can identify the better schools to send their kids to.

27 Walberg \& Bast 64-65

${ }^{28} 65$
Then, there is the reductio ad absurdum response to this objection: it applies to pretty much everything bought and sold in the market. There is asymmetric information about shoes, ships and sealing wax too. It is difficult, indeed, to name any good or service in which this "problem" does not exist. The logical implication is total socialism of the entire country, surely a problematic conclusion. ${ }^{29}$ How, then, can this "problem" be addressed? Simple, leave it the to the very institution under attack: free enterprise. That is why Consumers' Reports, Good Housekeeping Seals of Approval, Better Business Bureaus and Yelp exist: to help. Then, too, the asymmetric information issue applies to the public sector as well. But there, unhappily, people are compelled, as they are not in the private sector, to pay for and receive exactly what the bureaucrats offer them.

Another objection is that many private universities have succumbed to political correctness, which vitiates education: there are safe spaces, paranoia about microaggressions. Campus leftists have been removing statues and embracing cultural Marxism, none of which promotes learning. They have not yet gotten around to burning books; but they violently prevent the appearance of libertarian and conservative speakers. It is too much of a stretch to think they will not soon engage in that precise practice. Further, there is great bias in the professoriate. Academics on the left are vastly disproportionate on campus. ${ }^{30}$

A response to this objection is that many of these universities are "private" only

\footnotetext{
${ }^{29}$ Mises, 1922

${ }^{30}$ Langbert, 2018; Langbert, et al, 2016
} 
in the most limited sense. Most are heavily dependent upon government largesse, scholarships, research grants, etc. A significant proportion of their budgets comes from tax revenues.

Ultimately, Fahrenheit 451 offers a thought-provoking account of how we educate our children and encourages reflection on our current teaching practices. Bradbury does not directly address schools in his book, but the concept can be seen between the lines. Albeit prophetic, what remains scary is the similarity between Montag's world and the current reality. Little appreciation exists for learning. Much of the blame can be placed on the way we have structured our education system. The solution, as with any other economic institution, remains to introduce free market operations into schools. Once appreciation for the price system develops, we may see advancements in quality of schooling and education.

\section{Bibliography}

Boaz, David. Liberating Schools: Education in the Inner City. Cato Institute, 1990.

Bradbury, Ray. 1953 [2013]. Fahrenheit 451. New York: Simon \& Schuster. Print.

Brookes, Warren. "Public Education and the Global Failure of Socialism." Imprimis, vol. 19, no. 4, Apr. 1990.

Gardner, Howard. 2006. Multiple Intelligences: New Horizons in Theory and Practice, Basic Books

Gardner, Howard. 2011. Frames of Mind: The Theory of Multiple Intelligences, Basic Books Langbert, Mitchell. 2018. "Homogenous: The Political Affiliations of Elite Liberal ArtsCollege Faculty." Acad. Quest. (2018) 31:186-197; DOI 10.1007/s12129-018-9700-x; https:// link.springer.com/epdf/10.1007/s12129018-9700-x?shared_access_token=gp2rvi_
iDtlQtFfwLwOT9fe4RwlQNchNByi7wbcMAY6VS-9n0WALCjqT8pEbO7-xadb0R2 44aaF16x6E-Ch26FU5Z9ZKqKu88HBAJC KZSTb4_cMutGPHtjmD0_OnmTYdgYS5-VdrB0XC1ka4Sl19hVSvhDopTS6_WZeCjiR0Sk\%3D

Langbert, Mitchell, Anthony J. Quain, and Daniel B. Klein. 2016."Faculty Voter Registration in Economics, History, Journalism, Law, and Psychology." Econ Journal Watch. September, 13(3), 422-451. https:// econjwatch.org/articles/faculty-voter-registration-in-economics-history-journalis $\mathrm{m}$-communications-law-and-psychology. Leisey, Donald E., and Charles Lavaroni. The Educational Entrepreneur: Making a Difference. Edupreneur Press, 2000.

Leslie, Ian. Curious: The Desire to Know \& Why Your Future Depends on It. London: Quercus, 2015. Print.

Mises, Ludwig von [1922] 1981. Socialism: An Economic and Sociological Analysis. Translated by J. Kahane. Indianapolis: Liberty Fund. http://mises.org/books/socialism/contents.aspx

Mises, Ludwig von. Economic Calculation in the Socialist Commonwealth. Mises Institute, 2012.

Rothbard, Murray. Education: Free and Compulsory. Auburn: Ludwig Von Mises Institute, 1999. Print.

Rushdoony, Rousas John. The Messianic Character of American Education. The Craig Press, 1976.

Smith, AG. „Education in Seven Questions.” Mises Institute. N.p., 22 July 2011. Web. 20 Mar. 2018.

Underhill. „The Education Calculation Problem.” Altar \& Throne. N.p., 05 May 2016. Web. 20 Mar. 2018. 